\title{
Oceanisphaera donghaensis sp. nov., a halophilic bacterium from the East Sea, Korea
}

\author{
Soo-Je Park, ${ }^{1}$ Cheol-Hee Kang, ${ }^{1}$ Young-Do Nam, ${ }^{2}$ Jin-Woo Bae, ${ }^{2}$ \\ Yong-Ha Park, ${ }^{2}$ Zhe-Xue Quan, ${ }^{3}$ Deok-Soo Moon, ${ }^{4}$ Hyeon-Ju Kim, ${ }^{4}$ \\ Dong-Hyun Roh ${ }^{1}$ and Sung-Keun Rhee ${ }^{1}$
}

\begin{abstract}
Correspondence
Sung-Keun Rhee

rhees@chungbuk.ac.kr
\end{abstract}

\author{
${ }^{1}$ Department of Microbiology and Biotechnology Research Institute, Chungbuk National \\ University, 12 Gaeshin-dong Cheongju 361-763, Republic of Korea \\ ${ }^{2}$ Biological Resource Center, Korea Research Institute of Bioscience and Biotechnology \\ (KRIBB), Eundong 52, Yusong, Daejon 305-600, Republic of Korea \\ ${ }^{3}$ Department of Microbiology and Microbial Engineering, School of Life Sciences, Fudan \\ University, Shanghai 200433, China \\ ${ }^{4}$ Deep Ocean Water Application Research Center, Korea Ocean Research and Development \\ Institute (KORDI), 245-7 Oho-ri, Jugwang-myeon, Goseong-gun, Gangwon-do, 219-822, \\ Republic of Korea
}

A taxonomic study was carried out on two isolates, strains $B L 1^{\top}$ and $B L 11$, from marine sediment collected from the East Sea, Korea. Comparative 16S rRNA gene sequence studies showed that these isolates clearly affiliated with the Gammaproteobacteria. BL1 ${ }^{\top}$ and $\mathrm{BL} 11$ were most

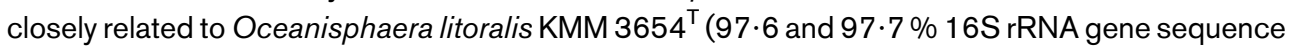
similarity, respectively). The level of $16 \mathrm{~S}$ rRNA gene sequence similarity between strains $B L 1^{\top}$ and $\mathrm{BL} 11$ was $99 \cdot 7 \%$. The two isolates were Gram-negative, aerobic, moderately halophilic, and grew in $0.5-8.0 \% \mathrm{NaCl}$ and at $4-42{ }^{\circ} \mathrm{C}$. Strains $\mathrm{BL} 1^{\top}$ and $\mathrm{BL} 11$ shared some physiological and biochemical properties with 0 . litoralis $\mathrm{KMM} 3654^{\top}$, although they differed in that $\mathrm{BL} 1^{\top}$ and $\mathrm{BL} 11$ were able to utilize ethanol, proline and alanine. The $\mathrm{G}+\mathrm{C}$ contents of the genomic DNA of strains $B L 1^{\top}$ and $B L 11$ were $56 \cdot 6$ and $57 \cdot 1$ mol\%, respectively. Both strains possessed $\mathrm{C}_{16: 1} \omega 7 \mathrm{c}$ and/or iso- $\mathrm{C}_{15: 0} 2-\mathrm{OH}, \mathrm{C}_{16: 0}$ and $\mathrm{C}_{18: 1} \omega 7 \mathrm{c}$ as the major fatty acids. DNA-DNA relatedness data indicated that strains $B L 1^{\top}$ and $B L 11$ represent a genomic species that is separate from $O$. litoralis $\mathrm{KMM} 3654^{\top}$. On the basis of polyphasic evidence, it is proposed that strain $\mathrm{BL}^{\top}{ }^{\top}(=\mathrm{KCTC}$ $12522^{\top}=\mathrm{DSM} 17589^{\top}$ ) represents the type strain of a novel species, Oceanisphaera donghaensis sp. nov.
The genus Oceanisphaera was created by Romanenko et al. (2003) to accommodate Gram-negative, aerobic, moderately halophilic, and oxidase- and catalase-positive species. At present, Oceanisphaera litoralis is the only species in this genus. During screening of manganese-oxidizing strains, two novel manganese-oxidizing bacterial strains, $\mathrm{BL}^{\mathrm{T}}$ and BL11, were isolated from marine sediment of the East Sea, Korea, and selected for further characterization by a polyphasic approach. $\mathrm{BL}^{\mathrm{T}}$ and BL11 were isolated using an artificial marine agar medium (Stein et al., 2001) containing $1 \mathrm{mM} \mathrm{MnCl} 2$. A sediment sample was placed in a sterile conical tube and diluted serially with filtered sea water. An

Published online ahead of print on 23 December 2005 as DOI 10.1099/ijs.0.64116-0.

The GenBank/EMBL/DDBJ accession numbers for the 16S rRNA gene sequences of strains $\mathrm{BL} 1^{\top}$ and $\mathrm{BL} 11$ are DQ190441 and DQ190440, respectively. aliquot of each dilution was spread on the solid medium and incubated at $17^{\circ} \mathrm{C}$ for 2 weeks. Colonies showing a brown colour on the medium were selected as manganese oxidizers (Stein et al., 2001). Single colonies were purified by transferring them onto new plates and subjecting them to an additional incubation for 3 days at $30{ }^{\circ} \mathrm{C}$. Cultured strains were stocked as a glycerol suspension $\left(20 \%\right.$, w/v) at $-70{ }^{\circ} \mathrm{C}$.

Bacterial genomic DNA was extracted using a commercial genomic DNA extraction kit (Bioneer). The 16S rRNA gene was amplified from the chromosomal DNA using the universal bacterial primer set (9F and 1512R) and purified PCR products were sequenced by Solgent (Daejeon, Korea) (Yoon et al., 1998). The full 16S rRNA gene sequences were compiled using SeqMan software (DNASTAR). The 16S rRNA gene sequences of related taxa were obtained from GenBank. Multiple alignments were performed with the program CLUSTAL_X (Thompson et al., 1997). Gaps were edited using 


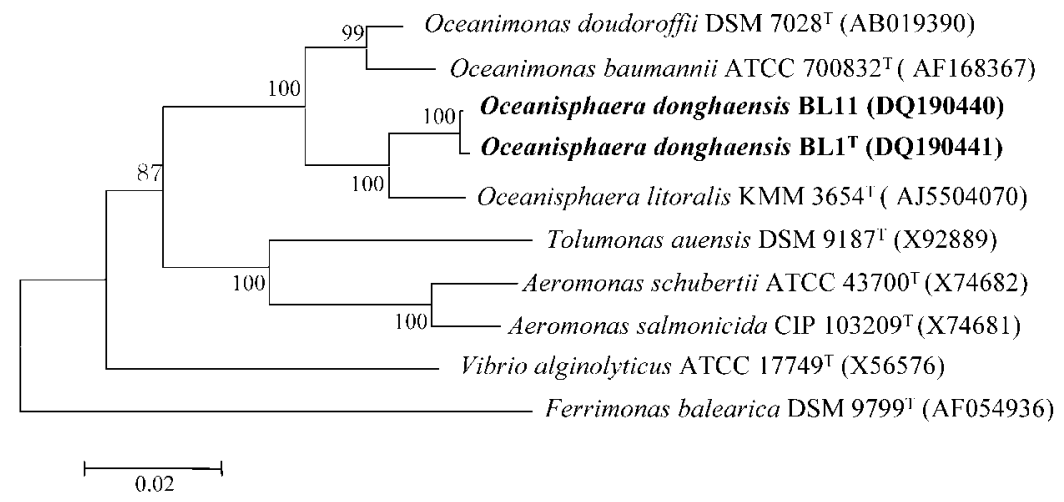
Fig. 1. Neighbour-joining tree showing the phylogenetic positions of Oceanisphaera donghaensis $\mathrm{BL} 1^{\top}$ and $\mathrm{BL} 11$ and their near- est neighbours based on 16S rRNA gene sequences. Bar, 2 substitutions per 100 nuc- leotide positions. Bootstrap values are expres- sed as percentages of 500 replications.

the program BIOEDIT (Hall, 1999). Evolutionary distances were calculated using the Kimura (1983) two-parameter model. Phylogenetic trees were constructed using the neighbour-joining method (Saitou \& Nei, 1987) with the program MEGA3 (Kumar et al., 2004); bootstrap values were based on 500 replications (Felsenstein, 1985). Phylogenetic analysis of strains $\mathrm{BL}^{\mathrm{T}}$ and $\mathrm{BL} 11$ revealed that they belong to the Gammaproteobacteria; the highest degrees of $16 \mathrm{~S}$ rRNA gene sequence similarity were found with Oceanisphaera litoralis KMM $3654^{\mathrm{T}}$ ( $97 \cdot 6$ and $97 \cdot 7 \%$, respectively), Oceanimonas doudoroffii DSM $7028^{\mathrm{T}}(96 \cdot 2$ and $96 \cdot 2 \%$, respectively) and Oceanimonas baumannii ATCC $700832^{\mathrm{T}}$ $(95 \cdot 1$ and $95 \cdot 2 \%$, respectively). In the phylogenetic tree (Fig. 1), strains $\mathrm{BL}^{\mathrm{T}}$ and BL11 clearly belonged to the lineage Oceanisphaera, as shown by the high bootstrap value $(100 \%)$.

The Gram reaction was performed by the non-staining method described by Buck (1982). Cell morphology was examined by light microscopy (Nikon) and transmission electron microscopy (Carl Zeiss) after negative staining with $1 \%(\mathrm{w} / \mathrm{v})$ phosphotungstic acid. Catalase activity was determined by bubble production in $3 \%(\mathrm{v} / \mathrm{v}) \mathrm{H}_{2} \mathrm{O}_{2}$ and oxidase activity was determined using $1 \%(\mathrm{w} / \mathrm{v})$ tetramethyl p-phenylenediamine. Strains BL1 ${ }^{\mathrm{T}}$ and BL11 were Gramnegative, spherical and aerobic (Fig. 2). Cells contained flagella and formed aggregates when cultivated in liquid media. Colonies grown on Marine 2216 agar plates (Difco) for 3 days were circular, convex, yellowish in colour and $1 \cdot 3-2 \cdot 0 \mathrm{~mm}$ in diameter. This result supports affiliation of strain $\mathrm{BL} 1^{\mathrm{T}}$ to the genus Oceanisphaera and differentiates it from members of the genus Oceanimonas.

Cellular fatty acids of strains $\mathrm{BL}^{\mathrm{T}}$ and $\mathrm{BL} 11$ were analysed after growth on trypticase soy agar (TSA; Difco) for 2 days. Cellular fatty acids were saponified, methylated and extracted according to the protocol of the Sherlock Microbial Identification System (MIDI, 1999). The fatty acids analysed by GC (Hewlett Packard 6890) were identified by the Microbial Identification software package. Chromosomal DNA extracted for $16 \mathrm{~S}$ rRNA gene amplification was used for determination of the $\mathrm{G}+\mathrm{C}$ content. RNA in the DNA solution was removed by incubation with a mixture of ribonuclease $\mathrm{A}$ and $\mathrm{T} 1$ (each at 20 units $\mathrm{ml}^{-1}$ ) at $30^{\circ} \mathrm{C}$ for $1 \mathrm{~h}$. The $\mathrm{G}+\mathrm{C}$ content of the chromosomal DNA was analysed as described by Mesbah et al. (1989) using reverse-phase HPLC. Phospholipid analysis was done as described previously (Komagata \& Suzuki, 1987; Vaskovsky et al., 1975). The major cellular fatty acid profiles of strain $\mathrm{BL}^{\mathrm{T}}$ and $\mathrm{BL} 11$ were composed of $\mathrm{C}_{16: 1} \omega 7 c$ and/or iso- $\mathrm{C}_{15: 0} 2-\mathrm{OH}, \mathrm{C}_{16: 0}$ and $\mathrm{C}_{18: 1} \omega 7 c$ (Table 1). These fatty acid profiles were similar to that of Oceanisphaera litoralis $\mathrm{KMM} 3654^{\mathrm{T}}$ (Table 1). However, there were differences in the proportions of fatty acids between this study and the study of Romanenko et al. (2003); these differences may be caused by different cultivation, extraction or analytical conditions. The $\mathrm{G}+\mathrm{C}$ contents of genomic DNA of strains $B L 1^{\mathrm{T}}$ and BL1 1 were $56 \cdot 6$ and $57 \cdot 1$ mol\%, respectively. BL ${ }^{\mathrm{T}}$ and BL1 1 contained phosphatidylethanolamine $(58.6$ and $54 \cdot 1 \%$, respectively) and phosphatidylglycerol (38.2 and $42.9 \%$, respectively) as the main phospholipids. The polar lipid profile of $\mathrm{BL}^{\mathrm{T}}$ and $\mathrm{BL} 11$ was similar to that reported for Oceanisphaera litoralis KMM $3654^{\mathrm{T}}$.

Utilization of various substrates as sole carbon source and some physiological characteristics were determined with API 32GN and API 20NE galleries according to the manufacturer's instructions (bioMérieux). Hydrolysis of

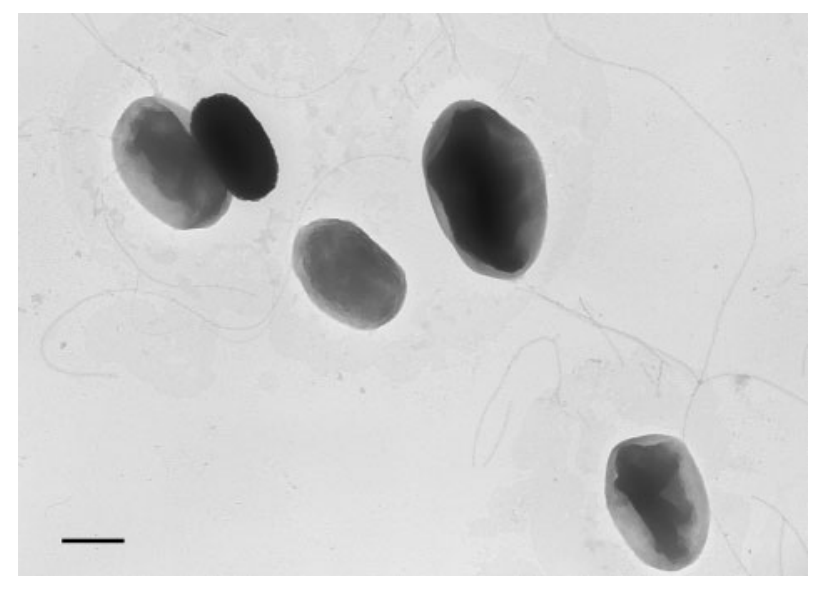

Fig. 2. Negatively stained transmission electron micrograph of Oceanisphaera donghaensis $\mathrm{BL} 1^{\top}$ cells. Bar, $0.5 \mu \mathrm{m}$. 
Table 1. Cellular fatty acid content (\%) of strains $B L 1^{\top}$ and $\mathrm{BL} 11$ and Oceanisphaera litoralis KMM $3654^{\top}$

Fatty acids representing less than $0.3 \%$ in all strains were omitted. ND, Not detected; ECL, equivalent chain-length.

\begin{tabular}{|lrcc|}
\hline Fatty acid & BL1 $^{\mathbf{T}}$ & BL11 & KMM 3654 ${ }^{\mathbf{T}}$ \\
\hline Straight-chain & & & \\
$\mathrm{C}_{12: 0}$ & $6 \cdot 09$ & $5 \cdot 45$ & $10 \cdot 31$ \\
$\mathrm{C}_{14: 0}$ & $0 \cdot 30$ & $0 \cdot 31$ & $1 \cdot 00$ \\
$\mathrm{C}_{15: 0}$ & $1 \cdot 01$ & $0 \cdot 35$ & $0 \cdot 46$ \\
$\mathrm{C}_{16: 0}$ & $15 \cdot 92$ & $19 \cdot 47$ & $16 \cdot 45$ \\
$\mathrm{C}_{17: 0}$ & $0 \cdot 53$ & $0 \cdot 67$ & $0 \cdot 30$ \\
$\mathrm{C}_{18: 0}$ & $0 \cdot 31$ & $0 \cdot 51$ & $\mathrm{ND}$ \\
Branched & & & \\
iso-C $16: 0$ & $1 \cdot 85$ & $1 \cdot 57$ & $0 \cdot 65$ \\
iso-C $17: 0$ & $0 \cdot 36$ & $0 \cdot 79$ & $\mathrm{ND}$ \\
Unsaturated & & & \\
$\mathrm{C}_{17: 1} \omega 8 c$ & $0 \cdot 68$ & $0 \cdot 42$ & $0 \cdot 39$ \\
$\mathrm{C}_{18: 1} \omega 7 c$ & $18 \cdot 66$ & $19 \cdot 07$ & $14 \cdot 01$ \\
Summed features & & & \\
2 & $5 \cdot 13$ & $5 \cdot 02$ & $8 \cdot 23$ \\
3 & $46 \cdot 20$ & $42 \cdot 39$ & $45 \cdot 08$ \\
7 & $0 \cdot 68$ & $0 \cdot 71$ & $\mathrm{ND}$ \\
Unknown $^{*}$ & & & $0 \cdot 64$ \\
ECL $14 \cdot 502$ & $0 \cdot 62$ & $0 \cdot 57$ & \\
\hline
\end{tabular}

${ }^{\star}$ Summed features represent groups of two or three fatty acids that cannot be separated by GLC with the MIDI system. Summed feature 2 contains one or more of iso- $\mathrm{C}_{16: 1} \mathrm{I}$ and/or $\mathrm{C}_{14: 0} 3-\mathrm{OH}$. Summed feature 3 contains one or more of $\mathrm{C}_{16: 1} \omega 7 c$ and/or iso- $\mathrm{C}_{15: 0} 2-\mathrm{OH}$. Summed feature 7 contains one or more of an unknown fatty acid of ECL $18 \cdot 846, \mathrm{C}_{19: 0}$ cyclo $\omega 10 c$ and/or $\mathrm{C}_{19: 1} \omega 6 c$.

casein, starch and Tween 80 was determined as described by Cowan \& Steel (1965) with modified artificial sea water. The artificial sea water contained (per litre distilled water) $23.6 \mathrm{~g}$ $\mathrm{NaCl}, 0.64 \mathrm{~g} \mathrm{KCl}$ and $4.53 \mathrm{~g} \mathrm{MgCl}_{2} \cdot 6 \mathrm{H}_{2} \mathrm{O}$ (Levring, 1946); rèactions were read after 5 days. Growth at different temperatures and $\mathrm{pH}$ was assessed after 5 days incubation. Salt tolerance was tested after 5 days incubation on artificial sea water supplemented with $0-15 \%(\mathrm{w} / \mathrm{v}) \mathrm{NaCl}$. On marine 2216 agar (Difco), strain $B L 1^{\mathrm{T}}$ was able to grow at $4-42^{\circ} \mathrm{C}$, but not at 2 or $45^{\circ} \mathrm{C}$. Comparative results of selective physiological characteristics of strains $B L 1^{\mathrm{T}}$ and BL11 and Oceanisphaera litoralis KMM $3654^{\mathrm{T}}$ are shown in Table 2.

DNA-DNA hybridization experiments were carried out with BL1 ${ }^{\mathrm{T}}$, BL11 and Oceanisphaera litoralis $\mathrm{KMM} 3654^{\mathrm{T}}$ using the method described by Ezaki et al. (1989). Strains $\mathrm{BL}_{1}^{\mathrm{T}}$ and BL11 showed less than $10 \%$ DNA-DNA relatedness with Oceanisphaera litoralis $\mathrm{KMM} 3654^{\mathrm{T}}$. The mean level of DNA-DNA relatedness between $\mathrm{BL}^{\mathrm{T}}$ and BL11 was $86 \%$. DNA-DNA relatedness data indicate that strains $\mathrm{BL}^{\mathrm{T}}$ and BL11 are representatives of a genomic species that is separate from Oceanisphaera litoralis KMM $3654^{\mathrm{T}}$.
Table 2. Differential phenotypic characteristics of strains $\mathrm{BL}^{\top}$ and $\mathrm{BL} 11$ and Oceanisphaera litoralis $\mathrm{KMM} 3654^{\top}$

Taxa: 1, Oceanisphaera donghaensis $\mathrm{BL1}^{\mathrm{T}} ; 2$, Oceanisphaera donghaensis BL11; 3, Oceanisphaera litoralis $\mathrm{KMM} 3654^{\mathrm{T}}$. Data for Oceanisphaera litoralis $\mathrm{KMM} 3654^{\mathrm{T}}$ were from Romanenko et al. (2003). All strains grow at $4-42{ }^{\circ} \mathrm{C}$ and are coccoid bacteria. All strains are positive for oxidase, catalase, $\mathrm{Na}^{+}$growth requirement, nitrate reduction, and malate and citrate utilization; all are negative for arginine dihydrolase, gelatin and aesculin hydrolysis, and utilization of caprate, galactose, glycerol, succinate, glucose, arabinose, mannose, mannitol, $\mathrm{N}$-acetylglucosamine, maltose, gluconate, adipate, sucrose, L-leucine, L-valine and L-tyrosine. All utilize Tween 80 weakly. Characteristics are scored as: $\mathrm{W}$, weak; + , positive; - , negative.

\begin{tabular}{|lccc|}
\hline Characteristic & $\mathbf{1}$ & $\mathbf{2}$ & $\mathbf{3}$ \\
\hline Cell diameter $(\mu \mathrm{m})$ & $0 \cdot 5-1 \cdot 5$ & $0 \cdot 5-1 \cdot 5$ & $1 \cdot 0-1 \cdot 2$ \\
Production of acid from: & & & \\
$\quad$ Citrate & + & - & + \\
$\quad$ Malate & $\mathrm{W}$ & $\mathrm{W}$ & + \\
Hydrolysis of: & & & \\
$\quad$ Urease & - & - & + \\
Utilization of: & & & \\
$\quad$ Phenylacetate & - & - & + \\
Ethanol & + & + & - \\
Phenol $\dagger$ & - & - & $\mathrm{W}$ \\
L-Glutamate & + & + & $\mathrm{W}$ \\
L-Proline & + & + & - \\
L-Alanine & + & + & - \\
DNA G + C content $(\mathrm{mol} \%)$ & $56 \cdot 6$ & $57 \cdot 1$ & $56 \cdot 4$ \\
& & & \\
\hline
\end{tabular}

${ }^{\star}$ Determined by API $32 \mathrm{GN}$ and $20 \mathrm{NE}$ tests (this study and Romanenko et al., 2003).

$†$ Phenol concentration $4 \mathrm{mM}$.

On the basis of morphological, physiological and chemotaxonomic characteristics, together with data from $16 \mathrm{~S}$ rRNA gene sequence comparisons described above, strains $\mathrm{BL1}^{\mathrm{T}}$ and BL11 represent a novel species, for which the name Oceanisphaera donghaensis sp. nov. is proposed.

\section{Description of Oceanisphaera donghaensis sp. nov.}

Oceanisphaera donghaensis (dong.ha.en'sis. N.L. fem. adj. donghaensis of Donghae, the Korean name for the East Sea in Korea from which the strains were isolated).

Cells are Gram-negative, oxidase-positive, catalase-positive, manganese-oxidizing and spherical. They occur singly and are $1 \cdot 0-1 \cdot 2 \mu \mathrm{m}$ in diameter. Contains a single polar flagellum. Moderately halophilic and grows in $0 \cdot 5-8 \cdot 0 \% \mathrm{NaCl}$ at $4-42{ }^{\circ} \mathrm{C}$. Favourable growth occurs aerobically producing circular colonies with regular edges within 2 days, with diameters of approximately $1 \cdot 3-2 \cdot 0 \mathrm{~mm}$. The type strain, $\mathrm{BL}^{\mathrm{T}}$, requires $\mathrm{Na}^{+}$for growth, reduces nitrate, utilizes malate and citrate, and is negative for arginine dihydrolase, 
gelatin and aesculin hydrolysis, and utilization of caprate, glycerol, succinate, L-leucine, L-valine and L-tyrosine. No acid is produced from galactose, glucose, arabinose, mannose, mannitol, $\mathrm{N}$-acetylglucosamine, maltose, gluconate, adipate or sucrose. Carbon and nitrogen source utilization and enzymic activities are shown in Table 2. The major cellular fatty acids of $\mathrm{BL1}^{\mathrm{T}}$ are $\mathrm{C}_{16: 1} \omega 7 \mathrm{c}$ and/or iso- $\mathrm{C}_{15: 0}$ 2-OH, $\mathrm{C}_{16: 0}$ and $\mathrm{C}_{18: 1} \omega 7 c$. Polar lipids of the type strain include phosphatidylethanolamine $(58.6 \%)$, phosphatidylglycerol (38.2 \%) and diphosphatidylglycerol (3.2\%). DNA $\mathrm{G}+\mathrm{C}$ content of strain $\mathrm{BL}^{\mathrm{T}}{ }^{\mathrm{T}}$ is $56 \cdot 6 \mathrm{~mol} \%$ (as determined by HPLC).

The type strain is $\mathrm{BL}^{\mathrm{T}}\left(=\right.$ KCTC $12522^{\mathrm{T}}=$ DSM $\left.17589^{\mathrm{T}}\right)$, isolated from marine sediment of the East Sea, Korea.

\section{Acknowledgements}

This research was supported by the Multipurpose Development of Deep Ocean Water Program from the Ministry of Maritime Affairs and Fisheries and grant MG05-0104-3-0 (the 21C Frontier Microbial Genomics and Application Center Program) from the Ministry of Science and Technology, Republic of Korea.

\section{References}

Buck, J. D. (1982). Nonstaining ( $\mathrm{KOH})$ method for determination of Gram reactions of marine bacteria. Appl Environ Microbiol 44, 992-993.

Cowan, S. T. \& Steel, K. J. (1965). Manual for the Identification of Medical Bacteria. London: Cambridge University Press.

Ezaki, T., Hashimoto, Y. \& Yabuuchi, E. (1989). Fluorometric deoxyribonucleic acid-deoxyribonucleic acid hybridization in microdilution wells as an alternative to membrane filter hybridization in which radioisotopes are used to determine genetic relatedness among bacterial strains. Int J Syst Bacteriol 39, 224-229.

Felsenstein, J. (1985). Confidence limits on phylogenies: an approach using the bootstrap. Evolution 39, 783-791.
Hall, T. A. (1999). BIOEDIT: a user-friendly biological sequence alignment editor and analysis program for Windows 95/98/NT. Nucleic Acids Symp Ser 41, 95-98.

Kimura, M. (1983). The Neutral Theory of Molecular Evolution. Cambridge: Cambridge University Press.

Komagata, K. \& Suzuki, K. I. (1987). Lipid and cell-wall analysis in bacterial systematics. Methods Microbiol 19, 161-206.

Kumar, S., Tamura, K. \& Nei, M. (2004). MEGA3: integrated software for molecular evolutionary genetics analysis and sequence alignment. Brief Bioinform 5, 150-163.

Levring, T. (1946). Some culture experiments with Ulva and artificial seawater. Kungl Fysiografiska Sällsk Lund Förhandlingar 16, 45-56.

Mesbah, M., Premachandran, U. \& Whitman, W. B. (1989). Precise measurement of the $\mathrm{G}+\mathrm{C}$ content of deoxyribonucleic acid by high-performance liquid chromatography. Int J Syst Bacteriol 39, 159-167.

MIDI (1999). Sherlock Microbial Identification System, Operating Manual, version 3.0. Newark, DE: MIDI.

Romanenko, L. A., Schumann, P., Zhukova, N. V., Rohde, M., Mikhailov, V. V. \& Stackebrandt, E. (2003). Oceanisphaera litoralis gen. nov., sp. nov., a novel halophilic bacterium from marine bottom sediments. Int J Syst Evol Microbiol 53, 1885-1888.

Saitou, N. \& Nei, M. (1987). The neighbor-joining method: a new method for reconstructing phylogenetic trees. Mol Biol Evol 4, 406-425.

Stein, L. Y., La Duc, M. T., Grundl, T. J. \& Nealson, K. H. (2001). Bacterial and archaeal populations associated with freshwater ferromanganous micronodules and sediments. Environ Microbiol 3, $10-18$.

Thompson, J. D., Gibson, T. J., Plewniak, F., Jeanmougin, F. \& Higgins, D. G. (1997). The CLUSTAL_X windows interface: flexible strategies for multiple sequence alignment aided by quality analysis tools. Nucleic Acids Res 25, 4876-4882.

Vaskovsky, V. E., Kostetsky, E. Y. \& Vasendin, I. M. (1975). A universal reagent for phospholipid analysis. J Chromatogr 114, 129-141.

Yoon, J.-H., Lee, S. T. \& Park, Y.-H. (1998). Inter- and intraspecific phylogenetic analysis of the genus Nocardioides and related taxa based on 16S rDNA sequences. Int J Syst Bacteriol 48, 187-194. 